\title{
Impact of climate change on water resources in Yongdam Dam Basin, Korea
}

\author{
Byung Sik Kim $\cdot$ Hung Soo Kim $\cdot$ Byung Ha Seoh $\cdot$ \\ Nam Won Kim
}

Published online: 19 October 2006

(C) Springer-Verlag 2006

Erratum to: Stoch Environ Res Ris Assess

DOI 10.1007/s00477-006-0070-5

Unfortunately the name of one author was misspelled.

The correct name is as follows: Nam Won Kim.

The online version of the original article can be found at http://dx.doi.org/10.1007/s00477-006-0070-5.

B. S. Kim $(\bowtie) \cdot$ N. W. Kim

Water Resources Research Department,

Korea Institute of Construction Technology,

2311, Daehwa-Dong, Ilsan-Gu, Goyang-Si,

Gyeonggi-Do, South Korea

e-mail: hydrokbs@kict.re.kr

N. W. Kim

e-mail: nwkim@kict.re.kr

H. S. Kim · B. H. Seoh

Department of Civil Engineering, Inha University,

Incheon 402-751, South Korea

e-mail: sookim@inha.ac.kr

B. H. Seoh

e-mail: seohhydro@inha.ac.kr 